\title{
Influence of Quality of Work Life and Job Attitude on Affective Commitment: A Study of Managerial Personnel
}

\author{
Amjad Ali ${ }^{*}$ and Abu SufiyanZilli ${ }^{\dagger}$
}

\section{Abstract}

The present study intends to understand the influence of managers' perception of quality of work life and job attitude on their affective commitment. The study was carried out in different private and public organizations/ companies located in New Delhi and its National Capital Region (NCR). Data was collected from 300 managers through convenience sampling method. Analysis of the data was done using stepwise multiple regression analysis and t-test. Results revealed that in private undertakings neither quality of work life nor job attitude predicted affective commitment of managers. Quality of work life predicted affective commitment of managers in public undertakings. Results further revealed significant difference between managers of private and public undertakings on all the measured variables such as Quality of Work Life, Job Attitude and Affective Commitment. The findings imply that organizations in both the sectors need to understand and manage managers' quality of work life and provide them with suitable interpersonal atmosphere to develop positive job attitude so that their level of affective commitment could be enhanced. Results are explained in the light of present scenario in existing private and public undertakings.

\footnotetext{
* Department of Humanities and Social Sciences, National Institute of Technology, Rourkela-769008, Odisha, India; amjad1737@gmail.com

† Department of Psychology, Aligarh Muslim University, Aligarh-202002, UP, India; profaszilli@gmail.com
} 
Keywords: Quality of work life; Job attitude; Affective commitment; Manager

\section{Introduction}

The present study is an attempt at developing an understanding of factors that make Indian organizations more effective. Specifically, it addresses questions related to the role that managers play in an organization. Factors like Quality of Work Life and Job Attitudes are seen as being influential in determining the commitment of managers towards their work and the organization as a whole.

The term Quality of Work Life appeared after Davis (1972) presented a paper in a conference at Arden House, US. Thereafter, the phenomenon of Quality of Work Life attracted the attention of psychologists, managers and supervisors for undertaking it as a philosophy or as an approach in designing the strategy for enhancing employees' well-being, attachment and involvement with the organization.

Quality of Work Life is a philosophy, a set of principles, which holds that people are the most important resource in the organization as they are trustworthy, responsible and capable of making valuable contribution to their respective organization, and hence should be treated with greater dignity and respect (Straw et al., 1984). The elements which are relevant to an individual's Quality of Work Life include the task, the physical work environment, social environment within the organization, administrative system and relationship between life on and off the job (Cunningham \& Eberle, 1990).

In fact, Quality of Work Life refers to "overall quality of human experiences in the workplace", or in other words, Quality of Work Life is the degree of excellence in work and working conditions which contribute to overall satisfaction of individual, thereby, enhancing the organizational effectiveness.

The present study defines QWL as good compensation, favourable conditions and environment, fair capacities of authority, rewarding potential growth and supportive organizational climate. Excellent 
work environment is seen to nurture employees' affective commitment.

Attitudes are propensities or tendencies to react in a favourable or unfavourable way toward an object. The object could be almost anything in the world around us. Attitudes reflect a person's likes and dislikes toward other persons, objects, events and activities in their environment. Strong attitudes such as attitudes toward supervision, pay, benefits, promotion or anything might trigger positive or negative reactions and affect a person's behaviour. Thus, employees' satisfaction and attitudes represent one of the key areas for measuring organizational effectiveness.

Job Attitudes can be defined as summary evaluations of psychological objects in the work domain. There are at least three broad categories of Job Attitudes, which have been frequently studied by researchers: task-based attitudes, people-based attitudes, and organization-based attitudes. Tett and Burnett (2003) have suggested that employees interact with three levels of their work environments on a daily basis such as the task level, the social level, and the organizational level.

\section{Organizational Commitment}

The concept of Organizational Commitment has grown in popularity in the literature on industrial and organizational psychology (Cohen, 2003). Employees' Organizational Commitment refers to the physical as well as behavioural involvement and attachment with the work and organization. According to Kanter (1968) Organizational Commitment can be defined as the willingness of workers to devote energy and loyalty to an organization. Kim and Hunter (1993) enumerated that Organizational Commitment is the employees' loyalty to the employer. Venkatachalam (1997) viewed Organizational Commitment as "talking on the organizational identity". In general, Organizational Commitment is considered as a useful measure of organizational effectiveness (Steers, 1975). In particular, "Organizational Commitment is a "multidimensional construct" (Morrow, 1993) that has the potential to predict organizational 
outcomes such as performance, turnover, absenteeism, tenure, and organizational goals" (Meyer \& Allen, 1997).

Meyer and Allen (1997) developed a framework of commitment on the basis of three components such as affective, continuance and Normative Commitment.

1. Affective Commitment refers to emotional attachment, identification with and involvement of an employee in the organization; i.e. an employee intrinsically desires to continue in the organization.

2. Continuance commitment, which relates to the cost the employee associates with leaving the organization i.e. the employee thinks that it is his or her need to continue working in the organization, and

3. Normative Commitment reflects a feeling of obligation to give back to the organization and an employee high on Normative Commitment would continue because he or she ought to do so.

However, the present study focuses only on Affective Commitment as it is found to be a more prominent commitment to the organization with the ideal of "I WANT TO".

An effective Quality of Work Life (QWL) is basically a tool to improve working conditions (an employee's perspective) and greater organizational efficiency (mainly from an employer's perspective). Positive results of QWL have been supported by a number of previous studies, among which is reduction in absenteeism, lower turnover, and improved job satisfaction (Havlovic, 1991; Cohen \& Gattiker, 1997; King \& Ehrhard, 1997). QWL does not only contribute to an organization's ability to recruit quality human capital, but also enhances the organization's competitiveness. Schurman (1998) concluded that employee satisfaction has always been an important management goal in job design and human resource policies.

Costello and Sang (1974) reported that majority of job incumbents of publicly owned utility firms were satisfied with security and social needs but, were different in the fulfilment of increase order needs self-esteem, autonomy and self-actualization. In a study 
conducted by Rhinehard and Dewolf (1969), the authors comparedmanagers working in government agencies with those from business and industries backgrounds. They found that perceived deficiency in need fulfilment was likely to increase successively at lower level which was almost similar to the findings of Jhonson and Marcrum (1968). Their study also revealed that increased dissatisfaction was found among managers of government agencies as compared to managers of business and industries.

Hartenstein and Huddleston (1984) enumerated that for Quality of Work Life measures to be successful, management and labour must have shared values. Without such values, managers are often authoritarian and deny workers sense of involvement, responsibility and autonomy, resulting in the workers lack of commitment and low productivity. On the other hand,Venkatachalamand and Velayudham(1997) found a significant positive relationship between Quality of Work Life and Organizational Commitment.

Based on literature review of Job Attitude research, Herzberg, Mausner and Snyderman (1959) developed a model of job satisfaction, which assumed that job satisfaction and dissatisfaction are not on opposite ends of a continuum, but are separate attitudes. Steers and Porter (1983), Walton (1985), and Miller and Monge (1986) confirm that proponents of job enrichment and quality-ofwork-life intervention have cited specific improvements in Job Attitudes, specifically job satisfaction and Organizational Commitment.

Job related attitudes play a major role in shaping the work behaviours of managers in organizations. Lynn, Lucy and George (1990) have developed a theoretical model to describe the differential relationship that organizational attitudes such as Organizational Commitment and satisfaction and Job Attitudes like Job involvement and satisfaction have with several behaviour intentions (turnover, absenteeism and performance).

Parker and Bradley (2000) found that the public-private distinction brings important differences not only in organizational structure, diversity of goals and resources but in Job Attitudes and 
behavioural intentions as well. Sahinidis and Bouris (2008) found a significant correlation between employees' organizational commitment, job satisfaction, motivation and their perceived training effectiveness which in turn improves training outcomes.

Researches in recent past have mainly focused on controllable external factors influencing Organizational Commitment such as modification of HRM policies and practices (Paul \& Anantharaman, 2004), increasing socialization (Mathieu \& Zajac, 1990), improving compensation (Mowday, Porter \& Steers, 1982; O'Reilly \& Chatman, 1986), leadership and interpersonal dynamics (Tu, Raghunathan, \& Raghunathan, 2001), and hygiene factors (Balaji, 1985; Khokle, 1998). Very few dispositional characteristics have been tested for their influence on an individual's organizational commitment.

Porter, Steers, Mowday and Boulian (1974) suggested that job satisfaction is changed more readily than organizational commitment, and therefore concluded that job satisfaction is also likely to be affected by a successful Quality of Work Life effort.

In another significant study, Allen and Meyer (1990) tested the aspect of three components (affective, continuance and normative) model of organizational commitment that integrates various conceptualizations (affective attachment, perceived cost and obligation). The results revealed that the affective and continuance components of organizational commitment are empirically distinguishable constructs with different correlates. The affective and normative components, although distinguishable, appear to be somewhat related. Thus the quality of the workplace is a vital factor in promoting organizational commitment. In contrast, good leadership and management may not guarantee committed employees. Samad (2007) found that committed and satisfied employees are normally high performers and contribute towards organizational productivity.

\section{Objectives of the Study}

Keeping in view the importance of Quality of Work Life, Job Attitude and Affective Commitment, the objectives of the present study may be stated as follows: 
1. To examine the influence of Quality of Work Life and Job Attitude on Affective Commitment among Managers of Private Undertakings.

2. To examine the influence of Quality of Work Life and Job Attitude on Affective Commitment among Managers of Public Undertakings, and

3. To determine the difference between managers of Private and Public Undertakings on Quality of Work Life, Job Attitude and on Affective Commitment.

\section{Hypotheses of the Study}

In the light of available literature related to the present study, the following hypotheses were formulated:

H-1: Quality of Work Life and Job Attitude has positive influence on Affective Commitment among Managers of Private Undertakings.

H-2: Quality of Work Life and Job Attitude has positive influence on Affective Commitment among Managers of Public Undertakings, and

H-3: Managerial personnel of private and public undertakings differ with each other on Quality of Work Life, Job Attitude and on dimensions related to Affective Commitment.

\section{Method}

\section{Participants}

The sample of the present research consisted of a total of300Managers $(\mathrm{N}=300)$. Of these, 150 each belonged to private and public undertakings. All the respondents were randomly selected from different parts of Delhi and its NCR (National Capital Region). The age of the sample ranged from 30 to 55 years. The data was collected from following private and public undertakings: Reliance, Airtel, Idea, Kingfisher, Britannia, Ultratech, Hero Honda, DLF, TMT, Maruti Suzuki, CMS, UTI Mutual Fund, Barclays Bank, Ottogon, Religare and MTNL, BSNL, NDPL, BHEL, GAIL, BRT, DDA, LIC, SBI, Allahabad Bank and IDBI Bank etc. The 
methodology of the study was planned systematically keeping in view its underlying objectives.

\section{Instruments}

Quality of Work Life Scale: This scale was developed by Shawkat and Ansari (2001).It assesses numerous dimensions of Quality of Work Life. This scale contains 48 items and is rated on a 5 point Likert scale ranging from 'strongly disagree' to 'strongly agree' with the possible score ranging between $48-240$. The reliability and validity of the scale is reported to be $\mathrm{r}=.70$ and $\mathrm{r}=.89$ respectively.

Job Attitude Scale: The Job Attitude scale was developed by Srivastava (1999). This scale comprises 15 true-keyed items. The 14 items of this scale was rated on 4-point rating scale i.e., Absolutely True, Almost True, Partially True, and False where as the final item i.e. 15th item of this scale was rated on 5-point scale i.e. Always, Quite often, Sometimes, Seldom, and Never. The reliability of this scale was found to be $\mathrm{r}=.79$.

Organizational Commitment Scale: The Organizational Commitment scale was developed by Shawkat and Ansari (2001). This scale contains 15 items and rated on 7 point rating scale ranging from strongly disagree to strongly agree with the score 15105. The reliability and validity of the scale was found to be $r=.80$ and $\mathrm{r}=.76$ respectively.

The analysis of the data was done using stepwise multiple regression analysis and t-test respectively.

\section{Results and Discussion}

The following sections discuss the results obtained in the research.

Table 1: Influence of Quality of Work Life and Job Attitude on Affective Commitment among Managers of Private Undertakings.

Results Obtained by Regression Analysis

Variables entered/Removed/a

a Criterion Variable : Affective Commitment.

Since none of the independent variables emerged as predictors of Affective Commitment among managers of private undertakings, 
results obtained in regression analysis have not been presented. The analysis showed that among both the entered independent variables i.e., Quality of Work Life and Job Attitude, not even a single variable emerged as predictor of Affective Commitment among managers of private undertakings. In other words it may be said that Quality of Work Life and Job Attitude do not influence the level of Affective Commitment among Managers of Private undertakings. Thus, the first hypothesis $(\mathrm{H}-1)$ of the present research was rejected.

Mathiew and Zajac (1990) found that commitment had a weaker relationship with job performance as compared to withdrawal behaviour and turnover. One widely held view is that attitudes are consistent forces in work behaviour. However, Lock and Lathan (1990) found only 3 to 4 percent variance of Job Attitude in the practical performance of Managers.

Table 2a and 2b: Influence of Quality of Work Life and Job Attitude on Affective Commitment among Managers of Public Undertakings.

Table 2a: Model Summary of Regression Analysis; Predictor: (constant), Quality of Work Life.

\begin{tabular}{|c|c|c|c|c|c|}
\hline \multirow{2}{*}{ Model } & \multirow{2}{*}{$\mathrm{R}$} & \multirow{2}{*}{$\begin{array}{c}\mathrm{R} \\
\text { square }\end{array}$} & $\begin{array}{c}\text { Adjusted } \mathrm{R} \\
\text { Square }\end{array}$ & \multicolumn{2}{|c|}{ Change Statistics } \\
\cline { 5 - 6 } & & & $\begin{array}{c}\mathrm{R} \text { Square } \\
\text { Change }\end{array}$ & $\begin{array}{c}\mathrm{F} \\
\text { Change }\end{array}$ \\
\hline 1 & $.222 \mathrm{a}$ & .049 & .043 & .049 & 7.696 \\
\hline
\end{tabular}

Table 2a shows the model summary indicating only one predictor of the model. Multiple correlation (R) was found to be 222 for Quality of Work Life. Further $R$ square which represents the contribution of predictor variables to the criterion variable was found to be .049. Another considerable aspect is R square change, which is the actual contribution of predictor variables to the criterion variable. The value of $\mathrm{R}$ square change came to be .049 which means that $4.9 \%$ variance was contributed by Quality of Work Life to the criterion variable (Affective Commitment). 
Table 2b: Coefficient: Criterion variable: Affective Commitment.

\begin{tabular}{|c|c|c|c|c|c|c|c|}
\hline Model & & \multicolumn{2}{|c|}{$\begin{array}{c}\text { Unstandardized } \\
\text { Coefficient }\end{array}$} & $\begin{array}{c}\text { Standardized } \\
\text { Coefficient }\end{array}$ & \multirow{2}{*}{ Sig. } & Correlation \\
\cline { 3 - 5 } \cline { 3 - 5 } & & $\mathrm{B}$ & $\begin{array}{c}\text { Std. } \\
\text { Error }\end{array}$ & Beta & & & partial \\
\hline 1 & (Constant) & 10.957 & 2.873 & & 3.814 & .000 & \\
\hline & $\begin{array}{c}\text { Quality of } \\
\text { Work Life }\end{array}$ & .056 & .020 & .222 & 2.774 & .006 & .222 \\
\hline
\end{tabular}

Table $2 \mathrm{~b}$ clearly indicates that only Quality of Work Life influences Affective Commitment of Managers of Public Undertakings. The statistical value given in the table indicates $t=2.774$ for Quality of Work Life, which was significant at .01 level of significance. The correlation (partial) was found to be $\mathrm{r}=.222$ for Quality of Work Life. Since t-value of Quality of Work Life was found significant, it means that Quality of Work Life positively influences the level of Affective Commitment among managers of public undertakings. Thus, it partially proves the second hypotheses (H-2) of the present research that Quality of Work Life and Job Attitude has a positive influence on Affective Commitment among Managers of Public Undertakings. These findings have been positively supported by Robert (1998) who revealed that Quality of Work Life plays a pivotal role in enhancing the commitment of employees which in turn leads to organizational development.

\section{Results Obtained by t-test}

Table 3: Means, SD and t-Values of Managers of Private and Public Undertakings on Quality of Work Life, Job Attitude and Affective Commitment.

\begin{tabular}{|c|c|c|c|c|c|}
\hline Variable & Group & $\mathrm{N}$ & Mean & $\mathrm{SD}$ & $\begin{array}{c}\mathrm{t}-\text { value } \\
(\mathrm{df}=298)\end{array}$ \\
\hline Quality of Work Life & Private & 150 & 169.11 & 24.64 & \multirow{2}{*}{$10.85^{*}$} \\
\cline { 2 - 6 } & Public & 150 & 141.39 & 19.29 & \\
\hline \multirow{2}{*}{ Job Attitude } & Private & 150 & 36.67 & 8.43 & \multirow{2}{*}{$11.95^{*}$} \\
\cline { 2 - 6 } & Public & 150 & 26.80 & 5.57 & \\
\hline Affective Commitment & Private & 150 & 23.48 & 3.84 & \multirow{2}{*}{$9.16^{*}$} \\
\cline { 2 - 5 } & Public & 150 & 18.85 & 4.84 & \\
\hline
\end{tabular}


The mean and SD in the case of managers of private undertakings for Quality of Work Life dimension were found to be 169.11 and 24.64 while in the case of managers of public undertakings the mean and SD were found to be 141.39 and 19.29 respectively. The tvalue between the two means was found to be 10.85 which were significant at 0.01 levels. The $t$-value between two means was found to be 11.95 which were significant at 0.01 levels.

Furthermore, the mean and SD in the case of managers of private undertakings for Affective Commitment dimension were found to be 23.48 and 3.84 while in the case of managers of public undertakings the mean and SD were found to be 18.85 and 4.84 respectively. The $\mathrm{t}$-value between the two means was found to be 9.16 which were significant at 0.01 levels.

The results obtained in Table 3 revealed that managerial level personnel of private undertakings had better Quality of Work Life, more positive Job Attitude and higher level of Affective Commitment as compared to the managerial level personnel of public undertakings. Thus, the third hypothesis (H-3) of the present research is accepted.

Rhinehard and Dewolf (1969) and Johnson and Marcrum (1968) simultaneously revealed that increased dissatisfaction was found among managers of public undertakings as compared to the managers of private undertakings. In the same manner Dhillon and Dandona (1988) found significant differences between managers of private and public banks on Quality of Work Life dimensions. On the other hand Parker and Bradley (2000) opined that the publicprivate distinction brings important differences not only in organizational structure, diversity of goals and resources but also in Job Attitudes and behavioural intentions as well. In the same vein Allen and Meyer (1990) revealed that the affective and continuance components of Organizational Commitment are empirically distinguishable constructs with different correlates.

\section{Conclusion and Implications}

In the present study, new ideas along with some old ones were explored. In response to the first objective of the study, not even a single independent variable emerged which influenced the 
Affective Commitment of managers of private undertakings. The result may be interpreted in a way that, managers' emotional attachment, identification and involvement with the organization was not influenced by quality of work life and Job Attitude. It means that Affective Commitment being the emotional part of the job has nothing or little to do with Quality of Work Life and Job Attitude as they are the part of cognitive aspects of the job. Whereas, cognition depends on real experiences, and emotions do not. The second and third objectives of the study however were met as results indicated significant positive influence of Quality of Work Life on Affective Commitment of managers of public undertakings and differences between managers of private undertakings and managers of public undertakings on all the measured variables.

The present investigation was conducted on a small sample of managers working in different locations of Delhi and its NCR, which may influence its generalizability. In order to widen its scope, a study on a larger sample from different parts of the country may be relevant. Studies on different levels of managers and with alternate socio-demographic variables from different organizations may also reveal interesting results.

\section{References}

Allen, N. J., \& Meyer, J. P. (1990).The measurement and antecedents of affective, continuance, and normative commitment to the organization. Journal of Occupational Psychology,63,1-18. http://dx.doi.org/ 10.1111/j.2044-8325.1990.tb00506.x

Balaji, C. (1985). Organizational commitment and human resource management: A study of managers in cooperatives. (Unpublished Doctoral Dissertation). Indian Institute of Management Ahmedabad, Ahmedabad.

Cohen, A. (2003). Multiple commitments in the workplace: An integrative approach. Mahwah, NJ: Erlbaum.

Cohen, A., \& Gattiker, U. E. (1997). Rewards and organizational commitment across structural characteristics: A meta-analysis. Journal of Business and Psychology, 9, 137-57.http://dx.doi.org/ 10.1007/BF02230633 
Costello, J. M., \& Sang, I. M. (1974). Need fulfilment and job satisfaction of professionals. Public Personnel Management, 3(5), 454-461.

Cunningham J. B., \& T. Eberle. (1990). A guide to job enrichment and redesign. Personnel, 67,56-61.

Davis, L.E. (1972). Paper presented at International conference, Arden House, Hariman New York, September, 25-29.

Dhillon, P. K., \& Dondona, N. (1988). Quality of work life and job involvement: A comparative study of managers of public and private banks. Paper presented at 25 th Annual Conference of Indian Academy of Applied Psychology, Hyderabad.

Hartenstein, A., \& Huddleston, K. F. (1984). Values: The cornerstone of QWL. Human Relations, 38(10), 65-66.

Havlovic, S. J. (1991). Quality of work life and human resource outcomes. Industrial Relations, 30(3), 469-79. http://dx.doi.org/10.1111/j.1468232X.1991.tb00799.x

Herzberg, F., Mausner, B., \& Snyderman, B. B. (1959). The Motivation to Work, New York, NY: Wiley.

Johnson, P., \& Marcrum, R. H. (1968). Perceived deficiencies in individual need fulfilment career army officers. Journal of Applied Psychology, 52, 457-461. http:/ /dx.doi.org/10.1037/h0026497

Kanter, R. M. (1968). Commitment and social organization: A study of commitment mechanism in Utopian countries. American Sociological Review, 33, 499-517. http:/ / dx.doi.org/10.2307/2092438

Khokle, P. W. (1998). Factors influencing commitment of key individuals towards and organizational transformation.(Unpublished Doctoral Dissertation). Indian Institute of Management Ahmedabad, Ahmedabad.

Kim, M., \& Hunter, J. (1993). Attitude-behaviour relations: A metaanalysis of attitudinal relevance and topic. Journal of Communication, 43, 101-142. http://dx.doi.org/10.1111/j.1460-2466.

Locke, E. A., \& Latham, G. P. (1990).A theory of goal setting and task performance. Englewood Cliffs, NJ: Prentice-Hall.

Lynn, M., Lucy, N. A., \& George, T.C. (1990).Job and organisational attitudes in relation to employee behavioural intentions. Journal of Organisational Behaviour,11(1), 57-67. http://dx.doi.org/ 10.1002/ job.4030110108 
Mathieu, J. E., \& Zajac, D. M. (1990).A review and meta-analysis of the antecedents, correlates, and consequences of organizational commitment. Psychological Bulletin, 108, 171-194.http://dx.doi.org/ 10.1037/0033-2909.108.2.171

Meyer, J., \& Allen, N. (1997).Commitment in the workplace. Thousand Oaks, CA: SAGE Publications.

Miller, K. I., \& Monge, P. R. (1986). Participation, satisfaction and productivity: A meta-analytic review. The Academy of Management Journal, 29(4), 727-753.

Morrow, P. C. (1993). Introduction: Understanding and managing loyalty is a multi-commitment world. Journal of Business Research, 26, 1-2. http:/ / dx.doi.org/10.1016/0148-2963(93)90038-Q

Mowday, R. T., Porter, L.W.,\& Steers, R.M. (1982).Employee organization linkages: The psychology of commitment, absenteeism, and turnover. New York, NY: Academic Press.

O'Reilly, C. A. I., \& Chatman, J. (1986). Organizational commitment and psychological attachment: The effects of compliance, identification, and internalization on pro-social behaviour. Journal of Applied Psychology, 71, 492-499. http:/ / dx.doi.org/10.1037/0021-9010.71.3.492

Parker, C., \& Bradley, L. (2000). Organizational culture in the public sector: Evidence from six organizations. The International Journal of Public Sector Management, 13 (2), 125-141. http://dx.doi.org/ 10.1108/ 09513550010338773

Paul, A. K., \& Anantharaman, R. N. (2004). Influence of HRM practices on organizational commitment: A study among software professionals in India. Human Resource Development Quarterly, 15, 77-88. http:/ / dx.doi.org/10.1002/hrdq.1088

Porter, L. W., Steers, R.M., Mowday, R. T., \& Boulian, P. (1974,). Organizational commitment, job satisfaction and turnover among psychiatric technicians. Journal of Applied Psychology, 59,603-609. http:/ / de.doi.org/10.1007/s11628-006-0015-6.

Rhinehard, B., \& Dewolf (1969). Comparative study of need satisfaction in government and business hierarchies. Journal of Applied Psychology, 53, 530-535.

Robert, K. T. (1998). Job involvement and organisational commitment as longitudinal predictors of job performance: A study of scientists and engineers. Journal of Applied Psychology, 82(4), 539-545. 
Sahinidis, A. G., \& Bouris, J. (2008). Employee perceived training effectiveness relationship to employee attitudes. Journal of European Industrial Training, 32(1), 63-76. http://dx.doi.org/ 10.1108/ 03090590810846575

Samad, S. (2007). Assessing the effects of job satisfaction and psychological contract on organizational commitment among employees in Malaysian SMEs. The $4^{\text {th }} S M E s$ in a Global Economy Conference.

Shawkat, S., \& Ansari, S. A. (2001).Organizational commitment scale. Unpublished Doctoral thesis, Aligarh Muslim University, Aligarh.

Srivastava, A. K. (1974). Job attitude scale. Varanasi: Rupa Publications.

Steers, R. M. (1975).Effects of need achievement on the job performancejob attitude relationship. Journal of Applied Psychology, 60, 678-682. http:/ / dx.doi.org/10.1037/0021-9010.60.6.678

Steers, R. M., \& Porter, L. W. (1983). Motivation and work behaviour. New York, NY: McGraw-Hill.

Straw, R. J., \& Heckscher, C. C. (1984).QWL: New working relationships in the communication industry. Labour Studies Journal, 9,261-274.

Tett, R. P., \& Burnett, D. D. (2003).A personality trait-based interactionist model of job performance. Journal of Applied Psychology, 88, 500-517.

Tu, Q., Raghunathan, B., \& Raghunathan, T. S. (2001). A path analytic study of the antecedents of organizational commitment of IS managers. Information Resource Management Journal, 14, 27-36. http:/ / dx.doi.org/10.4018/irmj.2001070103

Venkatachalam, J., \& Velayudham, A. (1997). Quality of work life: A review of literature. South Asian Journal of Management, 4(1), 45-57.

Walton, R. (1985). From control to commitment in the workplace. Harvard Business Review, 5-12. 